\title{
Natural Socio-Economic Environment and Sustainable Development of Rural Tourism: Case of Albanian Alps
}

\author{
M.Sc. Natasha Hoda \\ PhD Candidate, Agriculture University of Tirana \\ Email: natashahoda@yahoo.com \\ Doc, Dr. Hysen Hoda \\ University "Aleksander Moisiu", Durres \\ Email:hhodaj@yahoo.com

\section{Prof. Dr. Diana Shehu} \\ Agriculture University of Tirana \\ Email: esidial@yahoo.com
}

Doi:10.5901/mjss.2016.v7n5p426

\section{Abstract}

Tourism cannot be considered without the natural environment, economic and social development, while he has positive and negative impact on the environment. The tendency today is to minimize as much as possible the negative impact, with the aim to provide the needs of present and future generations. The environment is often used in his wider concept including various aspects such as natural environment, social and economic. The purpose of this article is to increase the knowledge of the readers about some concepts of the environment and tourism, to create a framework with some general and structural approach that can be widely used in practical management of sustainable development of tourism. This paper attempts to answer the following question: Have impact on sustainable development of rural tourism in mountainous and rural areas of Albania, natural and social economic environment? The methods that are used to test the hypothesis are explanatory methods. Using the empirical method (statistical) by means of statistical indicators as $R^{2}, R$, ANOVA and regression equation simple, we have concluded that natural and social economic environment has impact on the sustainable development of rural tourism. In the wider point of view the natural environment and cultural heritage of history belong to community of every country and some of them belong to the entire humanity of the world, so they all have the right to understand, appreciate and preserve the values of their national and international. At the globalization time, the protection, conservation, interpretation, and presentation of the different natural environment of any particular region or country, is an important challenge for people all over the world.

Keywords: Tourism, rural tourism, rural area, sustainability, rural development, sustainable development, natural and social economic environment

\section{Introduction}

The relationship between environment and tourism can be complicated, but it is very sensitive and closely. However, this connection affects every society to encourage people to become tourist, without neglecting the fact that the interaction that exists between tourism and the environment can be negative or positive impact. Negative impact can be categorized in various aspects. When mentioning the natural environment, we refer to two aspects, namely, the use of resources and pollution. If we talk about the expansion of tourism, it is clear that this development needs natural resources to facilitate the expansion of this sector. Two key natural resources that could be threatened by tourism are water and land, resources that are limited. Tourism uncontrolled and commercial presents the potential threats to many natural areas around the world, it can exert immense pressure on one area and lead to effects such as land erosion, growing pollution, discharge into the sea, loss of natural habitats, increasing pressure on endangered species and increase vulnerability to forest fires. In order to understand whether the relationship between tourism and the environment is a amicable or not, at first it is necessary to know how they can help each other. Environmental dimension represents the main attractions among different tourists in recent years. Considering that this paper focuses on rural tourism in the Albanian Alps area, we have chosen as a case study Thethi, Valbona and Vermoshin. These three areas have in common and differences 
among them about how rural tourism offer. During the contacts we have had with residents of the three areas, they have expressed that they see as a challenge the development of sustainable rural tourism, saying that we have many potential natural, cultural, historical, traditional but need more attention from the central and local government towards the infrastructure and superstructure for road as well as the training of the youth and guides specialists.

Vermoshi is a geographical entity and the urban part of the municipality's Kelmendi territory, with Tamar municipal center, in the district of the Great Highland. Vermoshi is the most northern region of Albania, and bounded on the west, north and east by Montenegro. Vermoshi is $31 \mathrm{~km}$ from the village of Tamara, Kelmend municipal center.

Thethi is a wonderful village in the region of Shkodra in northern Albania, which is located between the mountains of Shala and is almost isolated at the time of snow. Edith Durham, a famous English traveler and writer of the Balkans, visited the area of Theth in 1908. Thethi is frequented since the 1870 s by the Franciscans for tourism purposes, mainly in the summer, while by the end of 1945 the first camps were built in Theth and the Razem.

Tropoja district is located in northeastern Albania, mainly in the eastern Alps, among all the valleys or regions in Tropoje, most beautiful and most popular is Valbona valley. This valley is known not only for the rare natural beauty but also for the history of the sleigh, and takes its name from the river Valbona, which in Latin means 'good valley'. Valbona is one of the wonders of nature unique to the Albanian Alpine. Valbona Valley starts from the neck Valbona west and ends in the Drin valley southwest, it has a length of 50.6 kilometers. Somewhere to the north is a beautiful "princess" of the nature mother, that once stood surrounded inside the castle walls that form the mountains and now this "princess" is free thanks to the liberation of isolation that made poor road infrastructure, this is Valbona.

Tourism development has inevitable consequences, in many cases, environmental consequences. If the consequences are not managed appropriately, they can destroy the natural environment and natural beauties. Tourism and environmental management is almost a new phenomenon, as the tourism industry itself or even much younger than tourism, especially in terms of sustainable. Tourism activities and development should respect the degree of use of resources, nature and character of the region in which they are located. Rural tourism is an important phenomenon for sustainable economic development. Rural tourism is business activity like any other activity. However, if rural tourism is considered as an opportunity to eliminate the problems of rural development (and support their sustainable development), must comply regularly sustainability requirements with regard to socio-economic approach. The sustainable development of the region can be seen as quality of life, which means decent standard of living, public transport, infrastructure and public services; responsibility towards the environment and successful economy. Local communities should be encouraged and expected to participate in the planning, tourism development and control of government support. Special attention should be given to including indigenous people, women and minority groups to ensure equitable distribution of the benefits of tourism. Tourism is one of the most important industries in Albania. Due to its rapid growth, it exerts enormous pressure today on the environment, natural resources and culture of each country. Currently observed trend to increase profits in the short term without considering long-term effects on the environment constitutes one of the main concerns for the future of natural and cultural assets of the country. Sustainable development of rural tourism includes three essential element of sustainability: environmental sustainability, social sustainability and economic sustainability. On the one hand, if tourism planned poorly or developed profusely, it could become the destroyer of specific qualities that are essential for sustainable development. On the other hand, it may constitute moving force for preserving and promoting them directly through raising awareness and funds to support these values, or indirectly by providing an economic justification for withdrawing support by other partners. The development of sustainable rural tourism has an important role in development of rural areas, all actors involved in this type of activity should see this sector as an additional source of income and the government needs to pay equal attention to the development of sustainable of rural areas. To ensure a sustainable development of rural tourism must definitely interested all stakeholders involved such as local government, central government and the resident people. Creating a balance between the welfare of tourists, host communities and the environment, reducing conflict and recognizing mutual dependency, requires a special approach to destination management, sustainability should be linked with quality. Tourists know where the environment, employees and the local community, attention should be given most likely to show care and respect for them. Their motto today is "for the quality environment and for the host community developed, applies to spend, they also need to be promoted." Rural tourism with all kinds of his own is also a good opportunity to mitigate the seasonality of tourism in Albania, to extend tourism beyond the peak season which is the summer. Tourists who frequent the rural tourism (agro-tourism) have the opportunity to learn about cooking recipes local, and can and to participate in the preparation of their food, they also can frequent the local cultural feasts as "Day of Bjeshka " that organized every year on 25 June in Theth, tourism day organized in Vermosh annually on 19 June, and "Miss Bjeshka" that was organized in August in Vermosh. These celebrations are an opportunity for residents to advertise their products and fairs organized as part of these local feasts. Considering that rural tourism exists throughout the world, so distinctive character local variations in culture, customs, 
traditions, etc., Make rural tourism highly demanding. Although rural tourism offered by many countries not all are well organized in providing this product. National and regional level, more organized and specialized in the provision of rural tourism are France, Germany, Austria, and the United Kingdom, Italy has an excellent frame of rural tourism. The new member states of the EU have made great efforts and have achieved good results in respect of the management of rural tourism, it is worth mentioning Romania and Bulgaria with similar methods to make visitors welcome throughout the country, as well as Latvia where tourism development is strongly combined with other business activities. Tourists spend more than just a weekend in a rural accommodation are sure to have a story to tell when they return home.

Tourism represents one of the most buoyant sectors of the economy and in terms of jobs and wealth creation. It has the ability to stimulate regeneration and change in other areas and to increase confidence and pride of habitants in the rural area.

\section{Literature Review}

Review of literature in its totality represents the theoretical basis of research, which has of particular importance in its viability research. If the theory which is based research is appropriate then and research is built upon a strong base, so research without proper based on the theory is unacceptable. This is clearly expressed in the figure below, in which presented a research based on the correct theory and another one based incorrect theory.

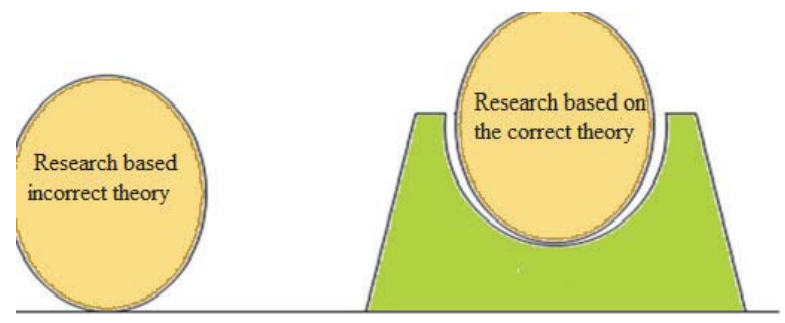

Figure 1. Research and theory

Initiated by the conceptual model of the research to talk about the theory and literature review we will begin with the concept of sustainable development of rural tourism in the mountain, but bringing different definitions associated to tourism as a concept and relevant literature, explaining what we call rural area and relevant literature, what is the development of sustainable and relevant literature, association with the tourism development and sustainability and literature, rural tourism and the types, will also handle the method of case study and literature associated with it. Swarbrooke (1999) noted that rural areas possess an important place in the culture of a country and the people of his own environment and rural means that civilization has grow. Rural areas have limited opportunities to develop this due to the topography and difficult climatic conditions. The basics of the concept of sustainable development found in studies associated with the environmental development of the 1960s and in identifying the connection between economic development and environmental degradation and pollution. This development was closely associated with the replacement of optimism about creating a utopia of modern technology with a new understanding of the forces contributing to the problems of the world. As well as other approaches (studies) related to the development, sustainable development as a phenomenon which has a big contribution on the improving of the human situation (living) but unlike many others, the development of sustainable highlights, not only economic growth, but it emphasizes the importance of a balance between economic growth and environmental protection. Different research were carried on the subject of sustainable development in the tourism industry that refer to different subjects such as the environment (Hunter \& Shaw, 2007), culture (Hawkin, 2004), politics (Yasarata et al, 2010), business (Tesone 2004, Dinan \& Sargean, 2000) and the economy (Tao \& Wall, 2009). Several attempts have been made to categorize the differences from one author to another for their way of the conception (Dahl, 1997, Allenby et al, 1998). These categorizations include a number of basic questions such as: What are the assumptions made about the relationship between humanity and nature? Nature has a value in itself (perceived value) or just about human interest? How much pollution the nature can withstand? What means equality and common responsibility? What should be the time frame and geographic boundaries of responsibility? What is the meaning of healthy economic growth? What is the role of the economy in sustainable development?

So that sustainability is a concept 'practical' ecological factors, economic factors and social-cultural factors of a 
community must be addressed should therefore be taken into account (Saarinen, 2006). Tourism is known to have positive effects and negative in terms of economic, social, and environmental (UN Environment Programme (UNEP) n.d.). A correlation exists between two variables when one of them is related to the other in some way (Triola,2008). Sustainable integration of environmental, social and economic help to minimize negative impacts, maximize the positive effects and has proven to have multiple business benefits (VAUGEOIS et al 2009; .Willard 2005; Savitz 2006).

\section{Research Methodology}

The methods used for testing the hypotheses raised are, descriptive methods and explanatory methods. The study presents a broad picture of rural tourism mainly in the study area by identifying the actual situation, the problems that hinder the development of sustainable rural tourism, measures that must be taken that this product affect as much as possible in diversification of tourism product whole of his own and achieve to change the mentality of seasonal tourism and the tourism extend beyond the period considered as the peak already. Data were analyzed by using various statistical methods, such as simple regeresioni, regression analysis with dummy variables, and structural equation modeling (SEM) to test the relationship between the dependent variable and one independent. As dependent variable in our search we have obtained Sustainable Development of Rural Tourism (SDRT) and independent variable we have obtained the natural, social and economic environment. An independent variable is the predictor variable which is supposed to be the cause of change in the dependent variable.

Once have done the pilot study we have observed that there is a connection between these two variables. The hypothesis that generates this paper is:

$\mathrm{H}_{1}$ : Natural and Social- Economic Environment (NSEE) is important and impact the Sustainable Development of Rural Tourism (SDRT).

In our case simple size of population includes all subjects that are categorized in one of the following groups, filed specialist (travel agencies, university teachers, students to branch hotel and tourism, a former student of this branch, etc.), residents, domestic tourists and foreign tourists, generally defined population is grouped as below:

- Filed specialist

- Residents

- Foreign tourist

- Domestic tourist

For the data processing was used SPSS statistical program, we will use alternate methods to avoid as much as possible error in reflection of reality, also this method is a useful approach, since it is based on questionnaire data.

\section{Analysis of the Data and Results}

The relationships between tourism and local natural heritage have of particular importance. Tourism can play a key role in generating awareness and support directly or indirectly to the preservation of these values. On the other hand, the quality of the natural and cultural heritage in many areas is essential for the generation of economic prosperity through tourism, improve the quality of life of local communities and experience of the visitors. The tables below represent the indicators raised by data processing on the basis of which will conclude.

Table 1. Model summary (NSEE- SDRT)

Model Summary

\begin{tabular}{|c|c|c|c|c|}
\hline Model & $\mathrm{R}$ & $\mathrm{R}$ Square & Adjusted R Square & Std. Error of the Estimate \\
\hline 1 & $.696^{\mathrm{c}}$ & .484 & .481 & .50151 \\
\hline
\end{tabular}

a. Predictors: (Constant)

C- Impact of NSE Environment on SDRT.

b. Dependent Variable: A- Sustainable Development of Rural Tourism (SDRT). 
Table 2. ANOVA

ANOVA

\begin{tabular}{|c|c|c|c|c|c|c|}
\hline & Model & Sum of Squares & $d f$ & Mean Square & $\mathrm{F}$ & Sig. \\
\hline \multirow[t]{3}{*}{1} & Regression & 42.049 & 1 & 42.049 & 167.184 & $.000^{c}$ \\
\hline & Residual & 44.770 & 178 & .252 & & \\
\hline & Total & 86.819 & 179 & & & \\
\hline
\end{tabular}

a. Predictors: (Constant), C,

C- Impact of NSE Environment on SDRT.

b. Dependent Variable: A- Sustainable Development of Rural Tourism (SDRT).

Table 3. Coefficients (ESNE- SDRT)

\section{Coefficients}

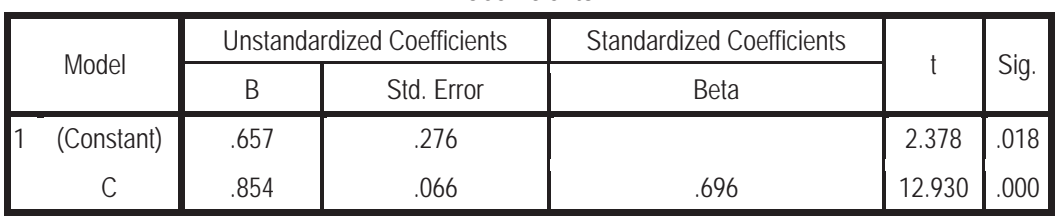

a. Predictors: (Constant), C,

C- Impact of NSE Environment on SDRT.

b. Dependent Variable: A- Sustainable Development of Rural Tourism (SDRT)

Based on the table above the linear regression simple equation has the following form:

\section{$\operatorname{SDTR}(\mathrm{Y})=0.657+1.854$ (NSEE)}

The equation represents the correlation between dependent variable the "Sustainable Development of Rural Tourism" and independent variable of Natural Social and Economic Environment.

By simple regression analysis, structural equation with categorical variables, we note $P_{\text {value }}$ and compare it with the coefficient a (0:05). In our case Pvalue $=(0.00)<(a) 0.05$, which means that the variable of Natural Social and Economic Environment is important for our model and has the significant effect to the SDRT. Initiated by result of the processing output of the indicator $\mathrm{R}=0.696$, that means the correlation between SDRT and NSEE is a strong positive. Statistical indicator $\mathrm{R}^{2}=48.4 \%$ indicates that the variance of the dependent variable depends on at the rate of $48.4 \%$ of the independent variable variance.

The natural environment is indispensable for the existence of rural tourism, so one of the reasons for which tourists undertake tours is natural attractions. Our country and especially in the Alps area which is the subject of this study is characterized by the unique beauty that has made that interviewed answered positively to relationship between this variable of nature social economic environment and SDRT. By the matrix of correlations (which provides the connections between variables created) we notice that is fulfilled the requirement that variable of natural socio-economic environment have correlation with the dependent variable of SDRT.

The sig.Pvalue $=0: 00$ so these value is to less than the value of $a=0: 05$, that means the effect is show to be significant, the condition (Pvalue $=00: 00)<(\alpha=0.05$ level) is completed, we have worked with credibility of $95 \%$.

Tabe 4. The results of hypothesis H1: impact of the nature social economic environment to the SDRT

\begin{tabular}{|c|c|c|c|c|}
\hline Hypothesis & Value of Sig & (Pvalue) & Statistical meaning & Testing of the hypothesis \\
\hline $\mathrm{H}_{1}: \mathrm{MN} \mathrm{SE} \rightarrow \mathrm{ZHQTR}$ & 0.000 & & $P<0.05$ & Proved \\
\hline
\end{tabular}

As a result we can say that nature social economic environment is important for the Sustainable Development of the Rural Tourism, $\mathrm{P}<0: 05$ and the variance of this variable influenced to the variance of SDRT, so the hypothesis $\mathrm{H} 1$ is accepted. 


\section{Conclusions and Recommendations}

- The sustainable development of rural tourism should be seen as closely relates with the development of rural disadvantaged areas.

- Tourism has become a more and more complex phenomenon, with political dimensions, economic, social, cultural, educational, bio-physical, ecological and aesthetic, while natural environment, cultural heritage, and their diversity constitute the main tourist attractions.

- Reaching proper correlation and desirable between tourism and the environment, or between expectations and aspirations of visitors and hospitality of local communities, potentially contradictory, they produce many challenges and opportunities.

- Based on empirical findings to determine the factors that have impact to the SDRT was reached be proven that: (i) Natural and socio-economic environment is important, and has a positive impact on the variable of SDRT.

- The findings of this study will be an orientation on the central and local state institutions to raise awareness on increased investment in rural areas in terms of road infrastructure, superstructures, as well as in the preparation of specialists for the tourism sector.

- The results of this research have the practical contributions to central and local institutions, tour operators, non-governmental organizations, with the aim of sustainable development of rural tourism should be considered as promoter of sustainable development of rural areas and the overall economy.

- Visa liberalization for the Europe countries, globalization and strong competition from neighboring countries in providing tourism product, are beginning to influence the way of doing business in Albania. This means that different businesses manufacturing or services should be oriented by the principles of sustainable development with the aim to motivate the long-term profit and with minimum negative impact on the natural environment, socio-economic and cultural of the destination.

- From the field survey and contacts as resident population and tourists we can say that Albania due to the values of cultural heritage continues to remain an attractive and available for all. Situated between two antique civilizations, the Greek and Roman, Albania inherited a valuable treasure of cultural assets, part of world cultural heritage. This rich heritage, is located everywhere, in parks and archaeological sites, in natural parks, in art galleries, archives photographic, forts and castles, in religious monuments and characteristic houses, the paths of stone, as well as in all museums. Albania has also refined collections that surprise everyone and that extend every area, from nature to art, from crafts to ethnology, from archaic to modern, from the religious to atheists, from the material to the spiritual.

- In the field survey, noted that the lack of a qualified specialist of tour guides who will add to the value of rural tourism product. In Valbona it has been established and is functioning "Association of accommodation in Valbona" which orients the foreign and local tourists with the necessary information. There is no such a association in Theth and Vermosh or in other areas of the country that offer rural tourism.

- Visa liberalization and membership of our country in international organizations such as NATO, has made favorable "climate security" in Albania, this has led to increasing the number of foreign tourists from all over the world visiting Albanian territory, and the rural areas which are frequented by international tourists. But increasing the pace of foreign and local tourists facing a lack of quality service, but also in the lack of capacity of the host destination.

- It was observed the lack of long-term strategy and sustainable and guided by the principles of sustainability and lacks a master plan for tourism development of rural areas, while available capacity for the design of these important documents exist.

- It was observed the lack of coordination and institutional cooperation (between central and local government) and lack of cooperation with private businesses.

- It is evident problem with the property law, as well as mortgaging them where residents have mortgaged only the surface of the housing and land space around sleigh while they are threatened spaces unregistered which may appropriated by persons who are not residents of the area and that could build off losing tradition countries (case Thethit).

- There is no accurate statistical data to identify and understand the tourism market. It was observed the lack of a database with official statistics on rural tourism as an important tourism product in its entirety, as an important source of income for residents of the destination as well as a very good opportunity to diversify the 
tourism product. The data source was directly from the field, municipalities and by asking the residents.

- Albania is a country with great tourism potential. Nature is indicated generous creating the possibility of a quantitative and qualitative tourist offer.

- But continuous Interventions and no criteria have led to great damage to nature, which of course will have their costs in tourism.

\section{References}

A.G. Krishna Menon (1993) Case Study on the effects of Tourism on Culture and the Environment

Abdoreza Faraji , Somayyeh Aghajani "Relationship between Tourism and Environment"

Alma Mastaka Gjografija Turistike e Shqipërisë

Anett Tizsér "Competitive tourism destination: developing a new model of tourism competitiveness"

Bertucci, G. (2002). Strengthening Local Governance in Tourism-Driven Economies. Statement prepared for the

Bërxholli dhe Xh Lleshi, Gjeografia 12, Trojet Shqiptare,

David A. Fennell "Ecotourism Programme Planning"

Dhoma e Tregëtisë dhe Industrisë Tiranë "Udhëzuaes mbi Zhvillimin e Qëndrueshëm të Turizmit në Shqipëri"

Dinica, V. (2006). Policy measures and governance for sustainable tourism and recreation in the Netherlands-an evaluation. Tourism, 54 (3), 245-258

Ebru Kerimoglu \& Hale Çiraci "Sustainable tourism development and a governance model for Frig Valley".

Elena Bellini, Ugo Gasparino William Malizia "Impact of Cultural Tourism uopon Rural Economies"

Elizabeth Kate Armstrong "Tourism destination recovery after the 2003 Canberra fires".

Felipe Ludena Vaquerizo "Rural Tourism Development in Nepal".

http://www.docstoc.com, Projektet e Produktit Turistik në Rajonin Turistik të Bjeshkëve të Nemuna ( Alpet Shqiptare) Prishtinë 2008.

J. Phillimore \& L. Goodson (Eds.): Qualitative Research in Tourism: Ontologies, Epistemologies and

Johns, N, \& Lee-Ross, D. (1998). Research methods in service industry management. London: Cassell,

Kevin K.F. Wong 7 Hoiyan Song, "Tourism Forecasting and Mrketing"

Komisioni Evropina Raport viti 2004" Analysis of mountain areas in EU member states, acceding and otherEuropean countries"

Libri "Malësia e Dangëllisë, pasuritë natyrore turizmi malor dhe zhvillimi i qëndrushëm. Nasip Meçaj.

Luca Jacopo Uberti Energjia dhe Turizmi në Shqipëri: Sfidat për zhvillim të qëndrueshëm mjedisor.

Lucinda Aberdeen\&Sigrid Schuler "Tourism impacts on an Australian indigenous community: a Djabugay case study"

http://www.sansebastianconference.com/en/downloads/papers/s1/CriticalContribution_FranciscoMadrid.pd

Masser, Y. \& Foley, P. (1987). Delphi revisited: expert opinion in urban analysis. Urban Studies, 24, 217-225.

Merton, R. K., Fiske, M, \& Kendall, P. L. (1990). The Focused Interview. New York: Free Press.

Musa Gashi "Bazat e turizmit", EMMKSK Prishtinë 1986

Nako Tashkov Tatjana Dzaleva Relationship Between Tourism Policy,Place Image and Business Investments

Natera, A. (2004). La noción de gobernanza como gestión pública participativa y reticular. Documento de trabajo nº 2/2004. Madrid: Universidad Carlos III de Madrid.

Nordin, S. \& Svensson, B. (2005). The significance of governance in innovative tourism destinations. ETOUR Working Paper 2005:2. Östersund: European Tourism Research Institute.

Oguztürk Bekir Sami, Seker Hilal\& Ertan Adnan "The Role Of Tourism In Regional Development"

Park, D. B. \& Yoon, Y. S. (2011). Developing sustainable rural tourism evaluation indicators. International Journal of Tourism Research, $13(5), 401-415$.

Peris, J. Acebillo, M. \& Calabuig, C. (2010). La Agenda 21 local como instrumento para la gobernanza democrática local. Colección AVANCES DE INVESTIGACIÓN, núm. 21, Fundación Carolina. CeALCI, Madrid.

Peters, G. B. \& Pierre, J. (2005). ¿Por qué ahora el interés por la gobernanza?. In A. Cerrillo (coord.), La Gobernanza Hoy: 10 Textos de Referencia (pp. 37-56). Madrid: Instituto Nacional de Administración Pública.

Pulido, J. I. (2005). Criterios para una política turística sostenible en los parques naturales de Andalucía. Sevilla: Consejería de Turismo, Comercio y Deporte, Junta de Andalucía.

Risi Albania "Tourism sector in Albania and business constraints to growth"

Roberson, Q. M., Collins, C. J. \& Oreg, S. (2005). The effects of recruitment message specificity on applicant attraction to organizations. Journal of Bussines \& Psycology, 19 (3), 319-340.

Rodolfo Baggio Network analysis of a tourism destination.

Rojo, A. (2005). La gobernanza: un modelo alternativo de gestionar el conflicto. Pensamiento Eixo Atlántico Do Noroeste Peninsular, 8, 5-30.

Schmidt, R. C. (1997). Managing Delphi surveys using nonparametric statistical techniques. Decisions Sciences, 28 (3), 733774.

Shanshi Li , Noel Scott and Gabby Walters "Current and potential methods for measuring emotion in tourismexperiences"

Skulmoski, G. J., Hartaman, F. T. \& Krahn, J. (2007). The Delphi Method for Graduate Research. Journal of Education Technology Education, 6, 1-21.

Spenceley, A. (2005). Nature-based Tourism and Environmental Sustainability in South Africa. Journal of Sustainable Tourism, 13 (2), 
136-169.

Veronica Wee, 120839"Capacity Development in the Tourism Industry A Case Study of Bali"

Yüksel, F., Bramwell, B. \& Yüksel, A. (2005). Centralized and Decentralized Tourism Governance In Turkey. Annals of Tourism Research, 32 (4), 859-886.

Yuri Niyazov, Carl Vogel, Richard, Price Michael MortonsonOpen Access Meets Discoverability.

Nako Tashkov Tatjana Dzaleva Relationship Between Tourism Policy. Place Image and Business Investments. 